\title{
THE AESTHETIC VALUES IN ANCIENT EGYPTIAN STRETCHERS AS A SOURCE OF CREATIVITY CONTEMPORARY PRINTING FORMULATIONS
}

\author{
Eman Abdullah Mohamed OTHMAN *
}

Art Education Department, Faculty of Specific Education, Assiut University, Egypt

\begin{abstract}
Peoples in the modern era are trying to find ways to defend their cultural identity, to preserve their privacy, and this responsibility rests with everyone, governments, peoples, intellectuals and artists. It is imperative for the person in general and the artist in particular to preserve his personality through His works in terms of the subject matter and the choice of the elements and techniques used to produce these works of art. Therefore, this research came to deal with the impact of the Egyptian identity as a source for the creativity of print paintings inspired by ancient Egyptian scrolls. The study began with an introduction on the importance of highlighting the Egyptian identity through art in light of technological development, through a descriptive study of selections from ancient Egyptian mushafs. The ancient (travel literature in Pharaonic Egypt) from the pre-dynastic era until the end of the modern state, in order to get acquainted with the plastic values of it, along with identifying the general features of ancient Egyptian art according to the different schools of art at the time, which are represented in idealism, realism, and the school in which it was mixed The two together, and the Atunian school), which these schools continued to exist throughout the various ancient Egyptian civilizations.

Keywords

The Aesthetic Values, Ancient Egyptian Stretchers, Creativity Contemporary, Printing Formulations.
\end{abstract}

\section{Introduction}

Peoples in the modern era try to find means to defend their cultural identity, to preserve their privacy, and this responsibility rests with everyone, governments, peoples, intellectuals and artists, so the person in general and the artist in particular must preserve his personality through his works in terms of the subject matter and the selection of the elements and techniques used In order to produce these works of art, this research came to deal with the impact of the Egyptian identity as a source for creating print paintings inspired by the ancient Egyptian masters. The study began with an introduction about the importance of highlighting the Egyptian identity through art in light of technological development, and then studying the descriptive anthology of the ancient Egyptian museums (travel literature in Pharaonic Egypt) until the end of the modern state, In order to get acquainted with the aesthetic values of God, while identifying the general features of ancient Egyptian art according to the different schools of art at the time, which are exemplary and realistic, the school in which the two blended together, and the Atonian school, which these schools continued to exist throughout the various ancient Egyptian civilizations. The objects and their values (plastic, aesthetic, expressive) are considered a powerful source for creating print paintings that express the Egyptian identity,

* Corresponding author: specedu@aun.edu.eg 
through the application of these plastic capabilities with different printing techniques, which are represented by (minotype, stenciling, direct drawing), as the researcher used types DifferentFrom printing pastes, represented in (bignite colorants, quinoa inks), where these techniques were chosen due to their change and development according to the different textures used, in addition to applying those colors using the selected techniques on a printed surface prepared by the researcher (pre-prepared), and that To emphasize the Egyptian Pharaonic identityThe research is titled: Aesthetic Values in Ancient Egyptian Stores as a Source for Creating Contemporary Formulations.

The objects and their values (plastic, aesthetic, expressive) are considered the source of creativity for print paintings that express the Egyptian identity, through the application of these plastic capabilities with different printing techniques, which are represented in (minotype, direct drawing), As the researcher used different types of printing pastes, represented by pigment colors, quinoa inks. (Pre-prepared), to emphasize the Egyptian Pharaonic identity. The study: The printing techniques have varied plastic values through different printing methods, and there is no doubt that recent scientific discoveries have led to the use of new techniques that have made this field richer, and the diversity of modern artistic trends has allowed the artist to choose what suits him in expressing his style, such as methods the performance With the technology used in printing, as well as the materials and their suitability for the technique and designs appropriate to the methods of performance, the print surface also plays an important role in emphasizing the texture required to be obtained to confirm the idea of the artistic work to be executed. It is noticeable that global influences dominate creativity to varying degrees, but the Egyptian identity has begun to be mixed with these influences and that the different artistic schools are a general artistic asset that can be studied and used, but at the same time we have to have our identity benefiting from our environment, and it should not be limited to keeping pace with development. Rather, we are pushing to contribute to it with something of our own personality. Hence the search for the Egyptian artistic personality invites us to dig into the spirit of this country and research For his sincere features, through ancient Egyptian art, as artistic value and plastic creativity, contemporary print formulations. Through the artist's search for everything new to satisfy his hidden desires for his ideas, he must take into account from time to time his identity and himself, which is considered his first line of defense against the conquest of globalization before he enters the world of global art in which works and features are similar, and this is one of the most important elements Preserving the special culture: 
1- Preserving customs, assets and traditions.

2- The appropriate selection of the new.

3- Defending the cultural roots.

4- Feeling of self and self-confidence.

5- Preserving the factors of identity and privacy.

6- The right approach and dealing with the other carefully.

\section{Research aims:}

1- Study the aesthetic values of ancient Egyptian museums to create print formulas that enrich the value of print paintings and express the originality and identity of the Egyptian artist.

2- Work on reviving the Pharaonic artistic heritage in a contemporary manner consistent with the environment and the requirements of the current era

3- Attempting to highlight the national character of our ancient arts through various printing techniques, to preserve the national identity in the era of globalization.

4- Linking contemporary printing techniques with a national heritage that still has many aspects that enrich modern artistic taste and achieve aesthetic value for printing paintings.

5- Competition before similar arts to foreign works of art. Research Hypotheses: The plastic vocabulary in the ancient Egyptian galleries, including the aesthetic values they carried, could be the source of innovation, new print formulas that enrich contemporary print paintings. The possibility of making use of the printing techniques represented in (menotype, direct drawing) in rooting the Egyptian identity, to create new print formulas that enrich contemporary print paintings. Research boundaries: the temporal boundaries: the archives of the pre-dynastic era the first transitional period and the middle state archives - the modern state museums. Spatial boundaries: Egypt. Substantive boundaries: - Technical and analytical study of models of scrolls in the different ancient Egyptian eras. - Dealing with the Minotype technique as a basic printing technique, to express those typographical formulas in a manner that achieves contemporary, and direct drawing technique, to create printed paintings that express the Egyptian identity, through the archives of ancient Egyptian art.

\section{Research methodology:}

The descriptive and analytical approach: through the technical and analytical study of selected models from ancient Egyptian mushrooms across different ages. The experimental method: the use of two printing techniques (Monotype, direct drawing), to create contemporary print formulas that enrich the printed works. Before exposure to how these different typographic methods were applied to my technique (monotype, direct drawing), it was necessary to briefly discuss travel literature in ancient Egypt and the artistic trends that prevailed in that period, as 
the research deals with the aesthetic values in travel literature in Pharaonic Egypt in the predynastic era., The Middle Kingdom, the New Kingdom), which was influenced by the ancient Egyptian art schools depending on each era.

\section{1-The ideal school:}

it is the one that expressed reality and showed its owners in the best possible way without looking at the moral faults of some of them, and it was limited to the royal family and the upper class.

\section{2- The realist school:}

It is the one that expressed the reality of its owners far from idealism, and sometimes expressed the reality of its time, and usually withdrew to the lower classes, where it showed them while performing their work, even if with their moral defects, without a strict commitment to the rules of lineage with regard to the person or the units that make up the subject In engraving and drawing.

\section{3- The school that combined idealism and protectionism:}

it emerged at some times, especially in the Middle Kingdom and in later ages, and it expressed in the statues of its owners from the royal family and senior statesmen something of idealism mixed with the reality of their physical formation, as well as the reality of their era, and perhaps the statues of some kings Twelfth Dynasty is good evidence of this.

\section{4 - The Atonian School:}

for which this name was chosen for reasons that are not available in the well-known traditional names, namely the art of Amarna and the art of Akhenaten, and among these reasons is that the signs of this art school appeared before the reign of Akhenaten, during the reign of his father Amun Hotep III at least, and continued after Akhenaten, during the reign of Tutankhamun, Ay, and Horemheb.

\section{Refernces}

- Stoddert, K., Treasures of Tutanhkmun, New York, 1976.

- Sztabi Nski Grzegorz Globalization Triada- 2002. and art -Lodzkie Towarzystwo Noukowe - The Epigraphic survey, the festival procession of opet in the colonnade Hail OIP 112, Chiago, 1994.

- Vandier, Manual d Archeologie, IV, Paris, 1965.

- Wilkinson, R., The complete temples of Ancient Egypt, New york, 2000.

- Woods, A Date for The Tomb of Seneb,at Giza, in Egyption Culture and Socitety / Studies Honor of Naguib Kanawati), vol ICairo, 2010. Sammry THE AESTHETIC VALUES IN ANCIENT. 
- Noha Sayed Mohamed AFIFI, Arafa Shaker HASSAN, PRODUCTION AN EXTERNAL CLADDING UNITS USING RUBBER MOLD AND POLYESTER, International Journal of Multidisciplinary Studies in Art and Technology, Vol. 2, No. 2, 2019, pp. 1-6.

- Hadeel Muhammad Aziz Nazmi SALEM, SPECIFIC SELECTIVE MEDIA INSPIRING IDEAS OF VISUAL EXPRESSION IN THE ARTISTIC SPACE: AN APPLIED STUDY IN THE FIELD OF PAINTING FOR THE INTERPHONE AND TRANSIENT EXHIBITION “THE MEDIUM SURVIVAL AND THE SURFACE IS A VISUAL PASSION”, International Journal of Multidisciplinary Studies in Art and Technology, Vol. 2, No. 2, 2019, pp. 7-11.

Received: February 5, 2020

Accepted: April 10, 2020 